Original Research Article

\title{
A prospective study on the prescription pattern of anti-cancer drugs and adverse drug reaction in a tertiary care hospital
}

\author{
Harshendra Guduru ${ }^{1 *}$, Santoshkumar R. Jeevangi ${ }^{2}$, Shantiling Nigudgi ${ }^{3}$, Smita V. Bhandare $^{2}$
}

${ }^{1}$ MBBS Student, ${ }^{2}$ Department of Pharmacology, Mahadevappa

Rampure Medical College,

Gulbarg, Karnataka, India

${ }^{3}$ Department of Oncology, HCG

Cancer Institute, Gulbarga,

Karnataka, India

Received: 16 October 2018

Revised: 15 November 2018

Accepted: 29 November 2018

*Correspondence to:

Dr. Harshendra Guduru,

Email: dr.harshendraguduru @ gmail.com

Copyright: (C) the author(s), publisher and licensee Medip Academy. This is an openaccess article distributed under the terms of the Creative Commons Attribution NonCommercial License, which permits unrestricted noncommercial use, distribution, and reproduction in any medium, provided the original work is properly cited.

\begin{abstract}
Background: Cancers is a group of disease involving abnormal cell multiplication with the ability to spread to other parts of the body. Common side effects seen with chemotherapy are fatigue, hair loss, easy bruising and bleeding, infection, anemia, nausea and vomiting, appetite changes, constipation etc. The need of this study is to evaluate the prescribing pattern and the adverse drug reaction associated with chemotherapeutic drugs. The study is aimed to analyze the prescribing pattern of anticancer drugs in medical oncology department of a tertiary care hospital, Karnataka.
\end{abstract}

Methods: An observational study was conducted on 30 patients of either sex admitted for chemotherapy for a period of 6 months in at HCG Cancer Institute, Gulbarga and Basaveshwar Teaching and General Hospital (BTGH), Gulbarga. The data collected is analysed statistically using descriptive statistics and presented as counts and percentages. Results are depicted in the form of tables. Results: A total of 30 prescriptions were collected with $10(33.3 \%)$ male and 20 $(66.6 \%)$ female. the maximum number of cases were noted in the age group of 46years to 55 years (10) and least in age group of 15-25 years having a single patient. In our study we found that more number of patients are breast cancer (12 patients) followed by cervical cancer and ovarian cancer (3 patients) and least are Ewing's sarcoma and Non-Hodgkin's lymphoma (1 patient). Most commonly prescribed anti-cancer drug is carboplatin and paclitaxel i.e. for 12 patients out of 30 patients, followed by cyclophosphamide for 10 patients and less commonly prescribed drug being dactinomycin and pemitrexate. Adverse drug reactions seen in maximum patients is hair loss among 20 pts followed by peripheral neuropathy (17) and taste change (16) and the less commonly noted side effects being chest pain and ototoxicity.

Conclusions: The study concluded that the drugs which were used in the treatment of various neoplastic conditions are in adherence and in accordance with the standard treatment guidelines and most of them were prescribed with generic name which leads to reduce in cost of treatment.

Keywords: Breast cancer, Chemotherapy, Mutation, Neoplastic disease

\section{INTRODUCTION}

Cancer is a neoplastic disease caused by mutation of the DNA of a cell which may be hereditary or sporadic. The term cancer refers to a group of disease involving abnormal cell growth with the potential to invade or spread to other parts of the body. ${ }^{1}$ These are in contrast to benign tumors, which do not spread to other parts of the body. The possible signs and symptoms usually include a lump, abnormal breathing, prolonged cough, unexplained weight loss, and a change in bowel movements. ${ }^{1}$ These symptoms usually indicate cancer, but they may have other causes also. Over 100 type of cancers are said to infect humans.

Tobacco use is associated with the cause of about $22 \%$ of cancer deaths. Other $10 \%$ are due to obesity, poor diet, lack of physical activity which might be due to professional stress or lifestyle modifications, and excessive drinking of alcohol. Some other factors usually include certain infections, exposure to ionizing radiation and 
environmental pollutants and contaminants. ${ }^{2}$ In this developing world about $20 \%$ of cancers are due to infections such as hepatitis $\mathrm{B}$, hepatitis $\mathrm{C}$ and human papillomavirus infections. These factors act partly by altering the genes of a cell altering their mechanism of function and replication. ${ }^{3}$ Many genetic changes are required before a normal cell develops into cancerous cell. It is estimated that about $5-10 \%$ of cancers are due to the inherited genetic defects from a person's parents. Cancer is usually detected by certain signs and symptoms or screening tests which are helpful in diagnosis of the disease and its extent. It is then typically further investigated by medical imaging and usually confirmed by biopsy and various other techniques. ${ }^{4}$ Many cancers can be easily prevented by not smoking, maintaining a healthy weight, not drinking too much alcohol and frequency of alcohol, eating plenty of fresh vegetables, fruits and whole grains, vaccination against certain infectious diseases, not eating too much processed and red meat, and avoiding too much sunlight exposure. ${ }^{5}$ Early detection through screening is useful in woman for cervical and colorectal cancer. ${ }^{6}$ Cancer is commonly treated with some combination of radiation therapy, surgery, chemotherapy, and targeted therapy, which aimed at reducing the tumor size and decreasing the spread of tumor. ${ }^{7}$ Pain and symptomatic treatment are an important part of care. Palliative care is important in people with advanced stage of cancer. The probability of survival depends on the type of cancer and the extent of disease prior to the start of treatment. ${ }^{8}$ In children under the age of 15 at diagnosis the five-year survival rate in the developed world is on an average of $80 \%$. $^{9}$

\section{According to cancer study in India}

- Estimated number of people living with the disease: around 2.5 million.

- Every year, new cancer patients registered: over 7 lakhs

- Cancer-related deaths: 5, 56,400

- Deaths in the age group between 30-69 years

- Total: 3, 95,400 (71\% of all cancer related deaths)

- Men: 2, 00,100

- Women: 1, 95,300

The drug utilization studies aim to evaluate factors such as prescribing, dispensing, administering and taking of medication, and its associated events (mostly beneficial). ${ }^{10}$ The studies are useful to provide denominators for calculating rates of the reported adverse drug reactions, and to monitor the utilization of drugs from therapeutic categories where particular problems can be anticipated. ${ }^{11}$ Drug utilization research was defined by WHO in 1977 as the marketing distribution, prescription and use of drugs in a society, with special emphasis on the resulting medical, social, and economic consequences. In a particular setting, it gives an idea about the prescribing practice and characterize the early signals of irrational drug use. With the help of WHO prescribing indicators it is possible to analyze the drug utilization pattern in our setting. ${ }^{12}$

\section{METHODS}

The prospective cross-sectional study was conducted for 6 months i.e. from February 2018 to August 2018 at Cancer care unit (BTGH), attached to M.R Medical College, Gulbarga and HCG Cancer Care Hospital, Gulbarga. The patients were recruited after obtaining an informed consent. The study protocol has been approved by the Institutional Ethics Committee of M.R Medical College, Gulbarga. About 30 prescriptions from the newly registered patients were included in the study along with a written performa. The patients were diagnosed with the clinical signs and symptoms of malignancy and later they were documented. In this drug utilization study, demographic characteristics such as age, sex and diagnosis are documented. Once consultation by the physician was over, the prescriptions were copied, and the patients were interviewed as per the WHO guidelines. The following WHO drug use indicators are determined.

\section{Inclusion criteria}

- Patients diagnosed with cancer and admitted for chemotherapy

- Individuals of either sex.

\section{Exclusion criteria}

- Pregnant and lactating mothers

- Patients with end stage cancer

- Children below 12years.

\section{Core indicators}

\section{Prescribing indicators}

Average number of drugs per counter was calculated. The percentage of drugs prescribed by the generic name was calculated. The percentage of drugs prescribed from the essential drug list was calculated.

Table 1: WHO prescribing indicators.

\begin{tabular}{|l|l|}
\hline Prescribing indicators & Data \\
\hline Average drugs prescribed & $2.06 \%$ \\
\hline Generic drugs & $96.84 \%$ \\
\hline IV fluids & $100 \%$ \\
\hline Injection & $100 \%$ \\
\hline On essential drug list & $94 \%$ \\
\hline
\end{tabular}

\section{Patient care indicators}

Average consultation time was calculated. The average dispensing time was calculated. Percentage of drugs which were actually dispensed was calculated.

\section{Facility indicators}

Availability of a copy of essential drug list. 
Table 2: WHO patient care indicators.

\begin{tabular}{|ll|}
\hline Average dispensing time (in sec) & $\mathbf{2 3 . 5 2}$ \\
\hline Drugs dispensed & $98 \%$ \\
\hline Adequate knowledge & $52 \%$ \\
\hline
\end{tabular}

\section{Complimentary indicators}

The percentage of patients who were treated without drugs was calculated by dividing the number of consultations in which no drug is prescribed by the number of consultations surveyed.

Table 3: WHO complimentary indicators.

\begin{tabular}{|ll|}
\hline Complimentary indicators & Data \\
\hline Without drugs & $00 \%$ \\
\hline
\end{tabular}

\section{RESULTS}

A total of 30 prescriptions were collected with $10(33.3 \%)$ male and $2(66.6 \%)$ female. The maximum number of cases were noted in the age group of 46years to 55years (10) and least in age group of 15-25years and 26-35years each having a single patient which can be noted down from Table 4.

Table 4: Age wise cancer pattern among adults.

\begin{tabular}{|ll|}
\hline Age & Count \\
\hline $15-25$ & 1 \\
\hline $26-35$ & 1 \\
\hline $36-45$ & 6 \\
\hline $46-55$ & 10 \\
\hline $56-65$ & 6 \\
\hline $66-75$ & 6 \\
\hline Total & 30 \\
\hline
\end{tabular}

Table-5: Pattern of cancer distribution among patients.

\begin{tabular}{|ll|}
\hline Cancer & Count \\
\hline Ca. breast & 12 \\
\hline Ca. cervix & 3 \\
\hline Ca. ovary & 3 \\
\hline Ca. pyriform sinus & 2 \\
\hline Ca. buccal mucosa & 2 \\
\hline Ca. lung & 1 \\
\hline Ca. stomach & 1 \\
\hline Ca. colon & 1 \\
\hline Ca. tongue & 1 \\
\hline Ca. hypo pharynx & 1 \\
\hline Ca. submandibular gland & 1 \\
\hline Non-Hodgkin's lymphoma & 1 \\
\hline Ewing's sarcoma & 1 \\
\hline Total & 30 \\
\hline
\end{tabular}

Table 6: Drug prescription pattern for various cancers.

\begin{tabular}{|ll|}
\hline Cancer & Total drugs \\
\hline Ca. breast & 6 \\
\hline Ewing's sarcoma & 6 \\
\hline Ca. ovary & 4 \\
\hline Ca. buccal mucosa & 4 \\
\hline Ca. cervix & 3 \\
\hline Non-Hodgkin's lymphoma & 3 \\
\hline Ca. pyriform sinus & 2 \\
\hline Ca. lung & 2 \\
\hline Ca. tongue & 1 \\
\hline Ca. stomach & 1 \\
\hline Ca. colon & 1 \\
\hline Ca. hypopharynx & 1 \\
\hline Ca. submandibular gland & 1 \\
\hline
\end{tabular}

Table 7: Combination of drugs used in various cancers.

\begin{tabular}{|c|c|}
\hline Cancer & Drugs prescribed \\
\hline Ca. breast & $\begin{array}{l}\text { Cyclophosphamide, docetaxel, } \\
\text { doxorubicin, epirubicin, } \\
\text { paclitaxel, 5-FU }\end{array}$ \\
\hline Ewing's sarcoma & $\begin{array}{l}\text { Cyclophosphamide, doxorubicin, } \\
\text { etoposide, vincristine, } \\
\text { ifosfoamide, dactinomycin }\end{array}$ \\
\hline Ca. ovary & $\begin{array}{l}\text { Carboplatin, paclitaxel, } \\
\text { gemcitabine, oxaliplatin }\end{array}$ \\
\hline Ca. buccal mucosa & $\begin{array}{l}\text { Carboplatin, paclitaxel, cisplatin, } \\
5-\mathrm{FU}\end{array}$ \\
\hline Ca. cervix & Carboplatin, paclitaxel, etoposide \\
\hline $\begin{array}{l}\text { Non-Hodgkin's } \\
\text { lymphoma }\end{array}$ & $\begin{array}{l}\text { Cyclophosphamide, doxorubicin, } \\
\text { vincristine }\end{array}$ \\
\hline Ca. pyriform sinus & Carboplatin, 5-FU \\
\hline Ca. lung & Carboplatin, pemitrexate \\
\hline Ca. tongue & Cisplatin \\
\hline Ca. stomach & Oxaliplatin \\
\hline Ca. colon & Oxaliplatin \\
\hline Ca. hypopharynx & Carboplatin \\
\hline $\begin{array}{l}\text { Ca. submandibular } \\
\text { gland }\end{array}$ & Carboplatin \\
\hline
\end{tabular}

The age wise distribution of the patient showed that there was higher incidence of cancer in this age group. The total incidence of the case constituted $33.3 \%$ of the total age group. Aging makes an organism susceptible to cancer due to hormonal disturbance increases in number of loci of chronic proliferation, and the decline in the immune surveillance. Exposure to infectious agents or creation of pro-oncogenic tissue microenvironment with increasing age can promote the development of cancer. In present study authors found that more number of patients are breast cancer (12 patients) followed by cervical cancer and ovarian cancer (3 patients) and least are Ewing's sarcoma and Non-Hodgkin's lymphoma (1 patient), which can be 
noted from Table 5. The number of drugs which were prescribed for various cancers is noted in Table 6.

Table 8: Drug prescription pattern.

\begin{tabular}{|ll|}
\hline Drugs prescribed & Count \\
\hline Carboplatin & 12 \\
\hline Paclitaxel & 12 \\
\hline Cyclophosphamide & 10 \\
\hline Doxorubicin & 6 \\
\hline 5-FU & 6 \\
\hline Epirubicin & 3 \\
\hline Oxaliplatin & 3 \\
\hline Etoposide & 2 \\
\hline Vincristine & 2 \\
\hline Cisplatin & 2 \\
\hline Docetaxel & 1 \\
\hline Gemicitabine & 1 \\
\hline Ifosfamide & 1 \\
\hline Dactinomycin & 1 \\
\hline Pemitrexate & 1 \\
\hline
\end{tabular}

Most commonly prescribed anti-cancer drug is carboplatin and paclitaxel i.e. for 12 patients out of 30 patients, followed by cyclophosphamide for 10 patients and less commonly prescribed drug being dactinomycin and pemitrexate, which can be noted in Table 8 .

Table 9: Adverse drug reactions among patients.

\begin{tabular}{|ll|}
\hline ADR & Count \\
\hline Hair loss & 20 \\
\hline Peripheral neuropathy & 17 \\
\hline Taste change & 16 \\
\hline Mucositis and Edema & 13 \\
\hline Nausea/Vomiting & 12 \\
\hline Eye and stomach pain & 11 \\
\hline Constipation & 7 \\
\hline Arthralgia and myalgia & 6 \\
\hline Increased urine output & 4 \\
\hline Breathlessness & 4 \\
\hline Pain at site of injection & 4 \\
\hline Diarrhea & 4 \\
\hline Headache & 4 \\
\hline Weight loss & 3 \\
\hline Decreased auditory function & 3 \\
\hline Back ache & 3 \\
\hline Convulsions & 3 \\
\hline Burning sensation in stomach & 2 \\
\hline Dyspepsia & 1 \\
\hline Wt. gain & 1 \\
\hline Chest pain & 1 \\
\hline Ototoxicity & 1 \\
\hline
\end{tabular}

Adverse drug reactions seen in maximum patients is hair loss among 20 pts followed by peripheral neuropathy (17) and taste change (16). While the less commonly noted side effects being chest pain and ototoxicity, which can be noted from Table 9. WHO prescribing indicators showed average number of drugs prescribed is 2.06 . The number of drugs prescribed by generic name is $96.84 \%$.

IV fluids were used for all patients and all the drugs were given in injectable form with $94 \%$ drugs being on the essential drug list. The WHO patient care indicators demonstrate that the average dispensing time is $23.52 \mathrm{~s}$ and the percentage of drugs dispensed are $98 \%$. The WHO complimentary indicators illustrate that treatment is not possible without prescription of drugs.

\section{DISCUSSION}

\section{Response to drug}

In present study mean age was $51.8 \pm 5$ years. Which was in comparison with the study by Jire et al, whose mean age was 52.24 \pm 8.66 years. ${ }^{13}$ In present study common anticancer drugs prescribed were: carboplatin, paclitaxel and cyclophosphamide. While in the study by Jire et al, cisplatin, paclitaxel, 5-FU were commonly used and cisplatin in study by John et al. ${ }^{14}$

ADRs observed in current study are nausea, vomiting, hair loss, peripheral neuropathy, taste change which were in comparison to study by Jire et al, where nausea, vomiting, alopecia, headache were common. ${ }^{13}$

Hair loss has been rated as one of the most distressing side effect of chemotherapy, along with nausea and vomiting by Yeager CE et al. ${ }^{15}$

To be of clinical interest a drug shall provide either measurable advantage to patients or to national health services. It shall be more effective than placebo or any other available treatment; if there is no noticeable advantage in terms of efficacy, it should be at least safer, more tolerable, easier to use. The outcome measures used shall be objective, assessing survival or quality of life of the patient.

As for safety is concerned, most drugs have caused the usual signs of cytotoxicity, neutropenia, thrombocytopenia, fever, infections, and gastrointestinal toxicity. In no instance did comparisons between the drugs show a clear-cut advantage, in terms of adverse reactions, over the reference drugs or other analogous agents. The Table 4 gives a brief description of new anticancer drugs approved for cancer chemotherapy in India.

\section{CONCLUSION}

The study concluded that, the drugs used in the treatment of various neoplastic conditions are in adherence with the standard treatment guidelines and most of them were prescribed with generic name which leads to reduce in cost of the treatment. Early recognition of the disease leads to a rational approach to case management and good clinical 
outcome. Pharmacovigilance should be the part of the patients care in order to reduce the occurrence of adverse drug reactions and also encourage the practitioners to report the ADR.

Table 10: Features of new anticancer drugs approved for cancer chemotherapy in India.

\begin{tabular}{|c|c|c|c|}
\hline Active substance & Indication & Mechanism of action & Safety notes \\
\hline Docetaxel & $\begin{array}{l}\text { Breast cancer, non-small cell } \\
\text { lung cancer }\end{array}$ & $\begin{array}{l}\text { Increased assembly of } \\
\text { microtubule }\end{array}$ & $\begin{array}{l}\text { Mutagenicity positive; } \\
\text { Carcinogenicity is not tested }\end{array}$ \\
\hline Paclitaxel & Soft tissue tumor & $\begin{array}{l}\text { Inhibition of microtubule } \\
\text { reorganization }\end{array}$ & $\begin{array}{l}\text { Mutagenicity positive; } \\
\text { Carcinogenicity is not tested }\end{array}$ \\
\hline Doxorubicin & Soft tissue tumor, ovarian tumor & DNA intercalation & $\begin{array}{l}\text { Mutagenicity positive; } \\
\text { Carcinogenicity is positive }\end{array}$ \\
\hline Cyclophosphamide & Breast cancer; ovarian cancer & DNA intercalation & $\begin{array}{l}\text { Mutagenicity positive; } \\
\text { Carcinogenicity is positive }\end{array}$ \\
\hline Docetaxel & $\begin{array}{l}\text { Breast cancer, advanced stomach } \\
\text { cancer }\end{array}$ & $\begin{array}{l}\text { Microtubule network } \\
\text { reorganization inhibition }\end{array}$ & $\begin{array}{l}\text { Mutagenicity positive } \\
\text { Carcinogenicity not tested }\end{array}$ \\
\hline Epirubicin & breast cancer & DNA intercalation & $\begin{array}{l}\text { Mutagenicity positive; } \\
\text { Carcinogenicity not tested }\end{array}$ \\
\hline 5-Fluorouracil & $\begin{array}{l}\text { Head and neck cancer; breast } \\
\text { cancer }\end{array}$ & $\begin{array}{l}\text { Interferes with DNA } \\
\text { replication }\end{array}$ & $\begin{array}{l}\text { Mutagenicity positive; } \\
\text { Carcinogenicity negative }\end{array}$ \\
\hline Etoposide & Ewing's sarcoma; uterine Cancer & $\begin{array}{l}\text { prevents re-ligation of the } \\
\text { DNA strands }\end{array}$ & $\begin{array}{l}\text { Mutagenicity positive; } \\
\text { Carcinogenicity is limited }\end{array}$ \\
\hline Rituximab & $\begin{array}{l}\text { Follicular } \\
\text { lymphomas }\end{array}$ & Bind to CD-20 & $\begin{array}{l}\text { Mutagenicity is not tested } \\
\text { Carcinogenicity is not tested }\end{array}$ \\
\hline Oxaliplatin & Colon cancer; rectal cancer & $\begin{array}{l}\text { Interfere with DNA } \\
\text { replication }\end{array}$ & $\begin{array}{l}\text { Mutagenicity positive; } \\
\text { Carcinogenicity positive }\end{array}$ \\
\hline Ifosfamide & $\begin{array}{l}\text { Ewing's sarcoma, germ cell } \\
\text { tumor }\end{array}$ & $\begin{array}{l}\text { Interfere with DNA } \\
\text { replication }\end{array}$ & $\begin{array}{l}\text { Mutagenicity positive; } \\
\text { Carcinogenicity positive }\end{array}$ \\
\hline
\end{tabular}

\section{ACKNOWLEDGEMENTS}

Authors would like to thank Dr. Smita Bhandare and Dr. Ameera Neelam, post graduate in Department of pharmacology, M.R. Medical College for their contributions to the preparation of this article.

Funding: No funding sources

Conflict of interest: None declared

Ethical approval: The study was approved by the Institutional Ethics Committee

\section{REFERENCES}

1. Park K. Park's Textbook of Preventive and Social Medicine. 23rd edition. Jabalpur: Banarasidas Bhanot; 2015:388.

2. World Health Organization. Fact sheet: Cancer Fact sheet, February 2018. Available at: http://www.who.int/en/news-room/factsheets/detail/cancer. Accessed 21 March 2018.

3. World Health Organization. Fact sheet: World Cancer Report 2014. Available at: http://www.searo.who.int/publications/bookstore/doc uments/9283204298/en/. Accessed 21 March 2018.
4. Kanwal R, Gupta S. Epigenetic modifications in cancer. Clin Genet. 2012 Apr;81(4):303-11.

5. Kushi LH, Doyle C, McCullough M, Rock CL, Demark-Wahnefried W, Bandera EV, et al. American Cancer Society Guidelines on nutrition and physical activity for cancer prevention: reducing the risk of cancer with healthy food choices and physical activity. CA Cancer J Clin. 2012 Jan-Feb;62(1):30-67.

6. World Health Organization. Fact sheet: World Cancer Report 2014. Available at: http://www.searo.who.int/publications/bookstore/doc uments/9283204298/en/ Accessed 21 March 2018.

7. National Cancer Institute. Fact sheet: targeted cancer therapies, 2012. Available at: http://www.cancer.gov/cancertopics/factsheet/Therap y/targeted\#q1. Accessed 9 June 2012.

8. Murthy NS, Rajaram D, Gautham MS, Shivaraj NS, Nandakumar BS, Pruthvish S. Risk of cancer development in India. Asian Pac J Cancer Prev. 2011 Jan 1;12:387-91.

9. Danaei G, Vander Hoorn S, Lopez AD, Murray CJ, Ezzati M, Comparative risk assessment collaborating group (Cancers. Causes of cancer in the world: comparative risk assessment of nine behavioural and environmental risk factors. Lancet. 2005 Nov 19;366(9499):1784-93. 
10. White MC, Holman DM, Boehm JE, Peipins LA, Grossman M, Henley SJ. Age and cancer risk: a potentially modifiable relationship. Am J Preventive Med. 2014 Mar 1;46(3):S7-15.

11. Lunde PK, Baksaas I. Epidemiology of drug utilizationbasic concepts and methodology. Acta Med Scand Suppl. 1988;721:7-11.

12. WHO Expert Committee on the selection and use of essential medicines. 2005. Accessible at: https://www.who.int/?ReturnUrl=http:\%2F\%2Fwww. who.int $\% 2$ Fmedicines $\% 2$ Fpublications $\% 2$ Fessential meds_committeereports $\% 2 \mathrm{Fen} \% 2 \mathrm{~F}$.

13. Jire AS, Bajait CS, Mahobia VK, Motghare VM. Study of prescription pattern and adverse drug reactions in patients with cervical cancer in tertiary care teaching institute. Int $\mathrm{J}$ Basic Clin Pharmacol. 2016;5(4):1594-7.
14. Lazarou J, Pomeranz BH, Corey PN. Incidence of adverse drug reactions in hospitalized patients: a metaanalysis of prospective studies. JAMA. 1998 Apr 15;279(15):1200-5.

15. Yeager CE, Oslen EA. Treatment of chemotherapy induced alopecia. Dermatol Ther. 2011 JulAug;24(4):432-42.

Cite this article as: Guduru H, Jeevangi SR, Nigudgi S, Bhandare SV. A prospective study on the prescription pattern of anti-cancer drugs and adverse drug reaction in a tertiary care hospital. Int J Basic Clin Pharmacol 2019;8:200-5. 